\title{
CONTRIBUIÇÃO À HISTÓRIA DA PUBLICIDADE NO RIO GRANDE DO SUL
}

\author{
Francisco Ricardo Rüdiger
}

A publicidade gaúcha figura hoje entre as principais do pais. constituindo o terceim mercido em volume de negócios de todo o Brasil Năo obstante, carecemos de estudos que revelem suas raizes, esclareçam seu desenvolvimento, contabilizem suas realizaçōes e possibilitem fazer seu diagnóstico na atualidade. Em suma, nossa publicidade padece de uma profunda falta de memória, náo conhece sua história.

$\mathrm{O}$ texto que se segue colige algumas notas de que dispomos sobre a questão, podendo servir como primeira contribuiçio para reverter este quadro e pồr em marcha uma linha de pesquisa sobre o tema. A matéria do mesmo trata do que, conforme nossa periodizaçào, podemos chamar de pré-história ou fase primitiva da propaganda no Rio Grande do Sul.

Conforme se sabe, 05 primórdios da publicidade no Estado săo relativamente recentes, remontam à conjuntura de surgimento e consolidaçio das primeiras agéncias merecedoras do nome, na década de 30. Desde logo, esqueçamos as pretensóes dos cronistas de plantāo, que gostariam de encontrar suas raizes nos bandos governamentais, no pregio dos caixeiros-viajantes, ou mesmo nos reclames e pequenos anúncios publicados nos jornais do século passado, a prova de suas primeiras manifestaçoes.

A prática sistemática e generalizada da propaganda comercial nấo surge por geraçâo espontănea ou simples vontade das pessoas, constitui o resultado de um certo nivel de desenvolvimento das forças produtivas e das relaçóes mercantis, que se estabelece com o progresso do capitalismo. Em nosso estado, a consolidação da produçấo fabril e a consequente formaçấo dos grandes mercados de consumo nos centros urbanos, que coincide com este estágio de desenvolvimento, nào se constitui senáo no curso dos anos 30 . A verdadeira fundaçào do negócio de publicidade de fato só ocorreu nessa época, especificamente, para valermo-nos de uma referência simbólica, em 1932, quando Arthur do Canto criou a agéncia Star Propaganda.

No século XIX, o modo de produçăo era pré-capitalista e as relaçôes mercantis se conservavam em embriāo, como provam os poucos reclames e anúncios publicados na imprensa. Os pequenos anúncios, que chamariamos

$$
\begin{array}{|l|l|l|l|l|l|}
\hline \text { R FAMECOS } & \text { Porto Alegye } & n .3 & p .42 .49 & \text { setembro 1995 } & \text { semestral } \\
\hline
\end{array}
$$


hoje de classificados, sầo mandados publicar predominantemente por pessoas privadas e referem-se a mercadorias e serviços que năo se enquadram no contexto de um verdadeiro mercado de consumo : remédios miraculosos, escravos, estojo com brasão da monarquia espanhola, escopeta com cabo de marfim, espeláculos circenses, efc. A propaganda comercial propriamente dita, feita por empresas para promover marcas, produtos e serviços, é praticamente desconhecida, porque o consumo constitui um gesto extraordinário ou satisfaz necessidades em termos que se baseiam muito mais na tradição do que no mercado.

Entretanto, na passagem do século este quadro comecou lentamente a mudar, em funçăo de vários processos verificados no periodo. Por volta de 1890, houve um surto de industrializaçào nas principais cidades do estado; notadamente no setor têxtil e alimentício. Porto Alegre, principalmente, viveu um momento de forte crescimento demográfico, que levou a populaçăo de 52 mil pessoas em 1890 para 130 mil em 1910. A cidade começou a ganhar uma série de melhoramentos urbanos, que contribuiram para tomá-la centro de consumo de todo o estado. As relaçóes șociais passaram por um processo de complexificaçaso, fazendo com que os homens começassem a se separar socialmente e a satisfazer suas necessidades por intermédio de mercado, pelo menos em Porto Alegre.

A fase primeva de desenvolvimento da publicidade gaúcha coincide precisamente com este periodo histórico. De fato, neste contexto começaram a surgir várias práticas e sujeitos sociais que, combinadas posteriormente numa mesma forma institucional, possibilitariam o nascimento da publicidade no Rio Grande do Sul.

Nessa perspectiva, o processo de declínio do jornalismo politico-partidário e ascensầo do moderno jornalismo industrial desempenhou significativo papel, na medida em que se constituiu num fator de aceleraçäo do desenvolvimento da atividade publicitária. No século XIX, os jornais nāo contavam com a receita proveniente da publicação de anüncios para se manter, sendo comum a recusa em aceitar publicidade entre as folhas literárias, como demonstra a repercussăo causada pela decisaio no sentido contrário tomada pelo periódico Murmúrios do Guaíba, em 1870. As novas publicaçōes, pelo contrário, procuram se organizar como verdadeiras empresas, capacitando-se para fazer da veiculaçăo de publicidade uma de suas principais fontes de receita.

Os jornais foram tomando consciência de que sua sobrevivência e progresso năo poderia depender mais exclusivamente dos seus assinantes e leitores, descobrindo na prestaço de serviço publicitário um significativo meio de desenvolvimento e sucesso. Em funçào disso, os departamentos comerciais começaram a se transformar de simples balcio de assinatura e recebimento de pequenos anúncios em verdadeiras gerências de publicidade, que providenciavam ou stugeriam a contrataçăo de certos profissionais para a criaçio do material de propaganda de seus clientes (C). O Diário, Porto Alegre, 13) 
VI1/1912). De certo modo, pode-se dizer que a modernizaçào dos jornais constituia um reflexo das mudanças verificadas na própria mentalidade empresarial em relaça à publicidade. Nessa mesma epoca, com efeito, os empresários começaram a tomar consciência do potencial de dinamizaçâo dos negócios contido na propaganda, passando a contratar, por conta própria, escritores e artistas com a funço de confeccionar anúncios, volantes e cartazes de publicidade.

Joầ Daudt de Oliveira, empresário do ramo farmacêutico, parece ter desempenhado um papel de liderança neste grupo, que, comvém notar, nāo constituia nem de longe a maiona do empresariado, mas sim uma espécie de vanguarda. Em pleno século passado, residindo no interior da provincia, ele já reclamava das condigôes adversas à praitica da publicidade em nosso estado, se dermos crédito às suas memórias, escritas nas primeiras décadas do século XX.

"Na falta de imprensa em que pudesse inserir anincios ou mesmo imprimir avulsos, em vez de jogar gamalo nas horas vagas, como faziam os boticários da época, eu empregava o termpo em escrever à mâo circulares e inúmeras cartas dirigidas aos moradores de fora, negociantes agricultores e estancieiros, nâo só de Santa Maria, como de São Vicente, Sảo Sepé, Cruz Alta e toda a regialo serrana." Joào Daudt de Oliveira : Memórias)

Posteriormente, tranferindo-se para a capital do estado e montando um estabelecimento de maior porte, onde fabricava xatopes, pomadas e tónicos (Bromil, Saúde da Mulher, etci, Daudt tornou-se um dos primeiros empresários a investir sistematicamente em propaganda, chegando ao ponto de contratar escritores, poetas e artistas para redigir e desenhar os anúncios de sua firma. Marcelo da Gama, por exemplo, trabalhou durante muito tempo com o empresírio, redigindo reclames de modo "que desde logo se revelou hábil, em prosa e versos belíssimos"

Nessa conjuntura, Daudt tomou-se também um dos primeiros a contratar os serviços de arte prestados pelos estudios e ateliers, que comegavam a surgir na cidade, para confeccionar seus anúncios, no que foi seguido por um número crescente de empresários, não somente na capital, mas no próprio interior do estado. Felipe leanselme da Silva, proprietário da Casa Aliança, que costumava contratar artistas plásticos para fazer os cartazes e quadros de anúncio de seu estabelecimento, passou a empregar regularmente os serviços destas oficinas de arte na virada do século, contribuindo para tornar conhecido o nome destes estúdios e ateliers.

Para se ter noçáo do significado que este cuidado teve no desenvolvimento das técnicas de propaganda em nosso estado, basta notar o tipo de critica que, em pleno avançado do século, podia ser encontrado na imprensa :

"O descaso na confecçato dos cartazes reclamistas qque se encontra nas ruas da cidade) tem levado algumas autoridades a pensarem na proibiçăo REVISTA FAMECOS 
dessas exibiçóes horripilantes e de suas figuras profundamente ridiculas." ("Indústria Pelotense - A Arte Lithográfica". In - A Opinião Pública,Pelotas, $9 / \times / 1924)$

Entre as casas que contribuiram para comegar a reverter este quadro, merecem mençào o estabelecimento fotográfico de Virgilio Calegari, a Studio de Arte Neos e o Atelier Seth. Em todas estas casas, fazia-se trabalhos de propaganda e criaçào publicitária, a pedido direto dos anunciantes ou solicitação do departamento comercial dos jornais, que funcionavam assim como intermediários do processo.

Paralelamente porém as próprias empresas, notadamente os estabelecimentos comerciais, começaram a criar seus próprios estúdios de arte, que, embora encarregando-se de tarefas diversas, acabaram-se transformando em verdadeiras oficinas de publicidade. Desses estúdios, que providenciavam desde a organizaçào de vitrines e decoração de interiores até a criaçăo de material de propaganda, o mais antigo parece ter sido fundado no final do século passado pela Casa Masson. Posteriormente, surguram vários outros, merecendo destaque, por motavos faceis de compreender, os estudios da Casa Neugebauer, da Casa Coates e da Livraria do Clobo.

As livrarias particularmente tiveram significativo papel na gênese da publicidade gaúcha. Em funçáo de suas atividades, estes estabelecimentos montaram os melhores estúdios de arte da época, para confeccionar nâo somente a capa e o desenho de suas publicaçóes, ou as peças promocionais dos livros que comercializavam, mas também o material de propaganda (cartazes, rótulos, embalagens, anúncios, clichês fotograficos, etc.) encomendado por terceiros, que contratavam os serviços grăficos destes estabelecimentos para confeccionar este material

As transformaçôes em curso e o desenvolvimento de uma nova mentalidade relativamente à propaganda podem ser avaliados tamberm quando se considera o caso das novas folhas de anúncio que comecam a surgir neste periodo. As folhas de anúncios nāo constifuiam novidade, na medida em que eram publicadas desde o século passado. Claude Dubreuil, responsável gráfico pela publicaçào de grande número de nossos primeiros jormais, publicou o primeiro deles, o sermanário $O$ Anunciante, entre $1832 \mathrm{e}$ 1835. Em Rio Grande, Antonio Caetano da Silva criou esta modalidade de periódico mandando publicar o Correio de Anúncios, em 1846. Finalmente, Cândido Augusto de Mello, homem de imprensa da fase heróica do jornalismo gaucho, publicou o mensirio O Grátis, em Pelotas (1854/55).

Na virada do século, estas folhas todavia comecam a sofrer uma série de transformaçóes, passando a ser publicadas por empresas e casas comerciais, que promoveram sua multiplicaça por todo o estado. Em Livramento, a Livraria Popular, por exemplo, fez publicar por essa época um jomal semanal deste tipo com o nome de A Propaganda (1911-1917). Em Rio Grande, a Associaçāo Comercial patrocinou a publicaçăo do semanairio O Anúncio (1902). 
Porém foi na capital ondée este tipo de publicaçào prosperou, devido sobretudo ao surto econòmico verificado à época. Franz Raths \& Cia., empresa comercial de importaça e exportaçato, por exemplo, publicou durante algum tempo o mensário O Anunciante Geral (1889 - i89|). A folha anunciava nas zonas de colonizaçaio alemă, onde tinha grande distribuiçầ, as promoçōes de venda que a empresa realizava em Porto Alegre. O Americano (1897) 1900), publicado pela farmácia do mesmo nome, circulava com o sugestivo slogan "Quem nâo anuncia nấo vende", e chegou a se tornar um periódico de fim-de-semana bastante prestigiado pela populaçaio da Capital.

Entretanto, mais significativo é o surgimento dos primeiros empresários especializados no ramo, nâo obstante o mesmo nâo constituir ainda uma prática essencialmente publicitaria, estando na dependência do trabalho de ediçio em geral. Amaldo Pereira foi um dos pioneiros nesse tipo de negócio, que se consolidou na década de 10. Em sesu pequeno escritório, de fato, ele não somente criou e redigiu vários periódicos de propaganda, como se fez publicitário, quando passou a oferecer aos seus anunciantes os serviços de "organizaçầo e redaçato de anúncios originais e de efeito" em seu conhecido Guia Comercial. Xisto Pereira ganhou notoriedade como ninguém neste tipo de empreendimento, que tendia cada vez mais a combinar o trabalho editorial com o trabalho de publicidade comercial, pelo fato de ter mantido durante vários anos a publicaçaio do mensário O Propagandista (19/0/1930).

Por volta de 1920, a publicaçào de anúncios tinha se tomado, por tudo is50, um grande negócio, que movimentava quantias relativamente altas e suscitava violenta concorrência entre os corretores credenciados nos departamentos comerciais das empresas jornalísticas. O Correio do Povo tinha se tranformado nầo somente num dos principais jornais, como no principal veículo de pequenos anúncios publicado no estado, gracas as sucessivas reformas em seu parque gráfico, que permitiram baratear seus custos e aumentar as tiragens. Para combatê-lo, vários jornais tentaram, sem sucesso, aumentar o volume de anuincios publicados, baixando o valor de suas tabelas. De fato, porém, havia se estabelecido uma liderança que surpreendia os contemporaineos, levando-os a denunciar o que chamavam de "monopólio da imprensa em Porto Alegre" :

"As tabelas de anúncios do Correio sâo tirânicas, exorbitantes, quase escandalosas, Pois nem assim os comerciantes deixam de drenaf para os cofres do Sr. Obino as supracitadas quantias que ali se pedem por trés dias de reclame," (A Época, Porto Alegre, 18/9/ 1922)

Em funçån disso, nâo surpreende que as práticas publicitárias, principalmente o negócio de veiculaçio de anúncios, começasse a se organizar empresarialmente. Os veículos tinham se modernizado: náo se confundia mais, nos balcôes dos departamentos comerciais, a publicaçăo de pequenos anúncios com a venda de espaço para propaganda. O processo de divisão social do trabalho progredia, estimulando o surgimento de uma divisâo técnica 
das tarefas referentes aे veiculaçào de propaganda comercial, notadamente o surgimento de intermediários entre as empresas e os veículos, que, cada vez mais conscientes desta conexio, se habilitam para realizar um trabalho especializado.

O mercado regional passo a passo progredia, despertando at atençào para empresas comerciais e industriais, inclusive de fora do estado, que faziam publicar anùncios atraves de agências paulistas e cariocas. Nessa época, realmente comecam a aparecer em nossos jormais reclames mais cuidados do ponto de vista artístico, confeccionados por profissionais especializados do centro do pais, conforme se pode verificar no material veiculado nesses anos por solicitaçào da pioneira do negócio publicitário brasileiro, à agência paulista A Eclética.

Nessa perspectiva, também nào é dificil compreender porque, paralelamente as empresas especializadas na publicaçào dos chamados periódicos comerciais, vajo surgindo empresas voltadas para o trabalho de veiculaça de material de propaganda em Porto Alegre. Entre elas, podemos citar a Empresa Anunciadora Contino (1915/7924), a Empresa Kosmos (1919) 1920\%, e a Agència Gaúcha (19/8/1926), que distribuia reclames e propagandas nấo somente nos jornais do estado, mas tambèm "em todos os grandes periódicos nacionais". Năo obstante, estas empresas nolo se especializam, misturam diversos tipos de trabalho e confundem funçós, contribuindo para manter o preconceito contra a atividade publicitána. Para se ter nocáo disso; basta notar que, resolvido a trabathar no ramo, Aristeu Pereira denomina a empresa que cria de *Agència de Empregos e Propaganda Comercial" (1922).

Na década de 20, comesaram a surgir, por outro lado, diversas empresas especializadas na prestaça de servico publicitário as empresas concessionárias de serviço público. O desenvolvimento urbano tinha estimulado a expansào destas uiltimas empresas, principalmente no setor de transporte, telefoniar e energia elétrica, criando um formidavel campo para açäo publicitaíria, na medida em que as vantagens do emprego de muitos destes senviços nào eram evidentes à época, precisavam ser explicadas à populaçáo. Para cuidar disso, foram se formando agências especializadas na criaçấo, confecçăo e veiculaçâo de painéis, cartazes e anúncios para estas companhias, que, solicitadas por outras empresas, desejosas de anunciar em suas dependências ou área de jurisdiçáo lestacóes ferrowiârias, bondes, postos de telefonia, etci, acabavam dando àquelas agèncias a concessío para explorar publicitariamente este negócio.

Raul Lagomansino, por exemplo, prestava serviço e explorava as concessôes publicitárias das companhias de telefonia e energia elétrica. L. S. Terra gerenciava a publicidade dos serviços de bondes. B. Garcia \& Cia., para nâo nos estendermos nos exemplos, cuidava da publicridade, da viação férrea, esclarecendo, nas páginas das revistas, que nåo somente fazia, colocava e conservava painéis, como criava e distribuia reclames em todo o estado, "dando

\section{REVISTA FAMECOS}


uma feiçâo mais artistica, elegante e chic, pelos cuidados que the merecem, à confeçào de anúncios" (Revista Máscara, Porto Alegre, 1926).

Nesta conjuntura, verificou-se finalmente a fundaçio das primeiras empresas de publicidade, a respeito das quais nâo dispomos porém de muitas noticias. Pelo que sabe, estas empresas vendiam serviços de confecçáo e veiculaçăo de anúncios, merecendo o conceito de verdadeiras agências de publicidade. Pelo pioneirismo e projeto, pelo menos duas lograram nos transmitir seu nome. A Empreza Rio Grandense de Publicidade, que parece ter sido a primeira agência a funcionar no estado, foi fundada em 1922. Conhecida como ERGA Ltda., contribuiu bastante para a melhoria do padrão estetico vigente nos reclames de jornal de seu tempo, cerrando suas portas por volta de 1932.

A Empreza de Propaganda Comercial, de que dispomos tambêm de poucas noticias, foi criada no final da década por comerciantes e industriais de Pelotas. Em 1930, tomou público seu projeto de estabelecer sua sede na capital do estado e criar filiais em várias cidades do interiot, mas de fato parece nāo ter realizado este plano (Cf, Terra Gaúcha, Porto Alegre, $8 / 1 X$ J 1930).

A explicaçăo para o fracasso dessas experiências não é dificil de compreender, quando se tem em mente que as condiçóes para a maturaçào da publicidade năo se consolidaram senào na década de 30 . Durante as primeiras décadas do século, verificou-se a gênese de diversas de suas práticas, mas nem por isso a publicidade deixou de ser vista com desconfiança, como um negócio suspeito, praticado por corretores de anúncio que batiam de porta em porta atrás de clientes, com o unico interesse de lesar o bolso do empresariado.

Por tudo isso, a suposiçầo de que a pré-história da publicidade gaúcha, como todo periodo desta natureza, foi feita de proezas e heroismo parece totalmente descabida. Em termos concretos, os progressos foram pequenos e dispersos, poucas pessoas viam na publicidade uma profissato de futuro, capaz de constituir sua própria esfera de valor. O negócio da intermediaçăo de reclames praticamente esgotava o conceito corrente de propaganda comercial, num mundo em que, nào obstante, estavam se gerando ats condiçoes para a admissato da tese conforme a qual "o anúncio nâo deve ser considerado como uma despesa, mas sim como um capital produtivo, "O Echo do Sul, Rio Grande, 12/11/1930). 